\title{
An Application of Arabic Language Teaching for Senior High Scholl: Communicative Approach
}

\author{
Akhmad Subekti Jiwandana ${ }^{1}$, Abdul Hafidz Zaid ${ }^{1}$, and Imam Bahroni ${ }^{1}$ \\ \{jiwandana2010@gmail.com; abuafadh@unida.gontor.ac.id; mas.bahroni@gmail.com\}

\begin{abstract}
${ }^{1}$ Departement of Arabic Language Teaching, Postgraduate Program, University of Darussalam Gontor, Jl. Raya Siman No.Km. 6, Dusun I, Siman, Kabupaten Ponorogo,
\end{abstract} \\ Jawa Timur 63471, Indonesia
}

\begin{abstract}
The Arabic language teaching at senior high school both public or private based on Islam as commonly called Madrasah Aliyah or Islamic School is always dealing with classic problems. The problems are the teaching period is limited, motivation and interest in learning Arabic, a background of student education, a variety of teacher's competence and experience in teaching, creating of language environment are difficult and textbook materials. This research that authors focused on textbook materials to obtain formulas or alternatives to foster student's interest in learning Arabic and their speaking skills. However, in practice, it still involves three other language skills indirectly, because the basic purpose of language learning is students can communicate. This research used to research and development (R\&D) Borg and Gall method level 4 that research and test to create products that do not yet exist. The result is authors have designed an Arabic language teaching material product in the form is a textbook material based on a communicative approach that is focused on speaking skills to foster student's interest in learning Arabic and them able to practice it in their environment.
\end{abstract}

Keywords: Arabic Language Teaching, Communicative Approach, Speaking Skills, Senior High School

\section{Introduction}

Foreign languages teaching in Indonesia as a second language from mother language that the general-purpose or can communicate with that language. There have been many books published on foreign language teaching, such as English, Arabic, German, Dutch, Mandarin, Japanese, etc. which offers a quick way to be a master of it. Many courses opened for foreign language teaching. This indicates an interest in learning any foreign language for specific purposes through means of textbooks or courses that are always in demand even the results are visible. Although, that the foreign languages teaching in classes such as most of which are already running, namely English and Arabic are a mandatory menu at every level of the school, in this case at senior high school.

Senior high school is divided into two kinds, both public and private. Specifically, then the two forms based on Islam which is commonly called the Madrasah Aliyah or Islamic School. The curriculum and textbooks are following the government or the Ministry of 
Education and Culture. The quantity of school is predicted growing every year. Until now, according to the data, the author was got the latest data in the year 2016, 763 public and 7.080 private, a total of it 7843 . This quantity is quite a lot as well as the potential to foster student's interest in teaching foreign languages, in this case, that the Arabic language which the authors were noticed it should be an important part besides pesantren for introducing the Arabic language in society. More than that, Muslims are the majority in Indonesia, where the Arabic language is an integral part of religion Islam.

Authors have the reasons for that which the focus to the foreign language here is the Arabic language because it has many virtues compared to other languages such as English, French, German, Japanese, Mandarin, etc. Some of it, that the God of Islam has been protecting the Arabic language among other languages and for Muslims or non-Muslims in a real and clear way which proved by making it as the language of Qur'an is maintained until the end of the day. Other evidence, the Arabic language is the language of science, culture, and Islamic civilization that is realized through the works of Muslim scholars has given us the benefits we can feel today [1]. Besides, the Arabic language is not stagnant with the era but can keep up with the current development suitable for the needs and all things that have emerged in various fields such as economics, politics, social, technology, etc [2]. This is the superiority of Arabic which is not just a language but there are important values from various sides if it studied more deeply.

Therefore that Arabic language teaching must be developed for other people in addition to the native speakers. This is because there are problems that arise in practice such as at senior high school as the researchers' focus in this paper. From the results of observations of researchers in the field and existing research sources [3] which the conclusion is not different such as the problems is teaching period is limited, motivation and interest in learning Arabic, background of student education, variety teacher's competence and experience in teaching, creating of language environment is difficult and textbook material. Because what is happening now is the Arabic language teaching with textbooks that already have material or content such as the researchers were noticed that teaching four language skills: listening, speaking, reading, writing at the same time with the conditions of the above problems do not have much influence. Therefore, researchers tried to make a textbook with the materials based on communicative approaches as a formula or alternative to foster student's interest in Arabic language focusing on speaking skills.

\section{Speaking Skills}

The meaning of speech or kalam is not only limited to kalam but there are several other terms that necessary to be known, in other words: al-Hadits, at-Tahadduts, al-Muhadatsah, and at-Ta'bir as-Syafahi. The first is kalam, according to some language experts, it means using language to express feelings, thoughts, information, and experiences to show certain intentions following the rules oral or written [4]. Besides that, it is interpreted as a unit of language unit whether it is long or short sentences are used for a specific purpose to his community [5]. It is also said as a form of language products during the communication process [6]. From these opinions, the simple meaning is to speak or express a certain purpose to anyone communicatively both oral and written under the context and the rules.

The second is al-Hadits, it is news which the contents can be short or long depends on a statement, expression or thought that all of which are the results of the speech [7]. Then the third is at- Tahadduts, according to Madkur as quoted by Salman Fayyadh et al. is the purpose of kalam and the ability of at-Ta'bir as-Syafahi regarding his feelings, 
social attitudes, politics, economy, and culture functionally and innovatively without speaking errors and good delivery [7]. Concluded from that, al- Hadits is a product of atTahadduts, it called news, pronounced by someone who can speak with certain intentions and neatly arranged in delivering it.

Afterward the fourth is al-Muhadatsah or called by al-Hiwar, in Latin it is called dialogues taken from Greek, called dialogos, it means is a written tittle that conversed by two or more people which the form of dialogue is clear and arranged [8]. Even so, it can be said an unwritten form or conversation form because, in essence, it is a meaningful free conversation, clear direction, and context suitable with the place that is communicated between two or more people. So al-Muhadatsah is a general form, can be written or unwritten form, it has clear meaning and purpose, because al-Muhadatsah is more common than kalam, al-hadits, and at-Tahadduts or all three of these are covered in al-Muhadatsah, notice the picture as below: 


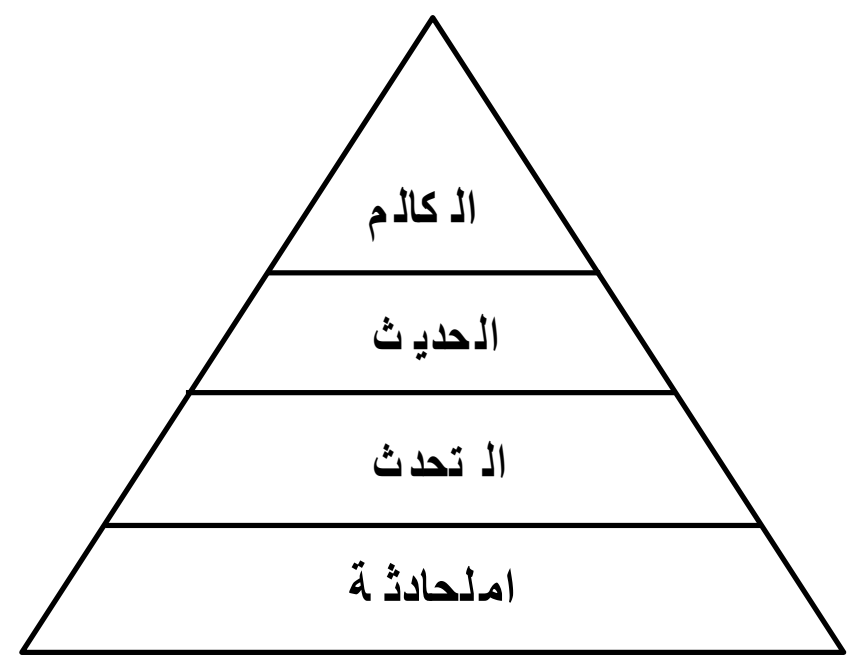

Fig. 1. Pyramid Speaking

But the last is not included in the part of the pyramid above, namely at-Ta'bir as-Syafahi, it shows the kalam of the mind expressed eloquently. This is because at-Ta'bir as-Syafahi there are steps as though: thinking carefully before expressing it by determining the important points, limiting the words according to the conditions in which he will speak, using the right vocabulary to facilitate the listener to understand and to say with the right words without a doubt. Thus, the definitions of the terms above concluded that the position of speaking skills in teaching foreign languages in this case which the focus is the Arabic Language must be emphasized more because it already involves the other three skills.

This is because as one of the four language skills in teaching a language that the speaking skills or kalam are a real simple indicator that a person can express a second language or a foreign language when a student is learning it. As it is confirmed by Rusydi Ahmad Thu'aimah that speaking skills one of the basic abilities show us the success of language learning goals [9]. More details were revealed by Mahmud Ahmad Sayyid if it is proficient in the ability to communicate about himself and socialize in his environment. Therefore, if it is concluded that the success of one's language teaching in a simple and real way can be seen from its ability to be able to communicate with others.

For this reason, a process of speaking is necessary because speaking skills are not easy. That the environment speech process is a stimulus, thinking, a form of expression, and saying or speaking. Stimulus so that the child is provoked or motivated to speak and has a picture of what he will say. This can be given by giving examples of conversations or by a question and answer directly expressed by the teacher first for example. Furthermore, involving students to think after being motivated to speak. Then the process of selecting an expression form to express what is already in his mind by determining the pronunciation, vocabulary, expressions and appropriate arrangement. At the end of this, students must speak as well as possible trying to minimize mistakes. So in this final process, the teacher must pay attention to what the students say [2].

Then to the speaking process is not just talking, without direction, it is necessary to know the kinds of aims and forms. Noticed from the objectives there are two kinds such as speaking functionally and speaking creatively. The first purpose is used to meet the needs of 
daily living needs and official needs such as information leaflets, announcements, instructions, official letters, teaching, research, provisions, etc. in schools, universities or foundations. Whereas the second is more about art such as poetry, drama, stories, public speaking, etc. As for the form, there are two in Arabic language teaching where the teacher needs to pay attention to it so that classroom teaching goes well. First, speak freely, that is the teacher allows the students to freely choose the title he wants to express. Second, speaking bound, it is the teacher who limits the titles expressed by the students such as speaking about how to communicate in schools, airports, hospitals, markets, restaurants, etc [4]. Thus, Arabic language teaching in the classroom is expected to run effectively and efficiently if the objectives and forms are clear and this is very helpful for schools that have fewer study hours such as those in senior high school if compared to pesantren.

Another important thing after that is the urgency of teaching in Arabic language teaching. As explained by Muhammad Sholahuddin Mujawir quoted from Ahmad Ibrahim Shuman that speaking skills are in the first position. Explained by Muhammad Sholeh Samak that education experts agree developing students' speaking skills is in the spotlight of the main goal of language teaching, so students learn to speak and listen before learning how to read and write because this is an effective way of preparing students to read and write [10]. This is emphasized by Yusuf Shumaili kalam is the pillar of dialogue or conversation which is the key at the basic level of teaching for all titles and learning material without exception. Also, speaking is a form of direct and fast communication between someone and the other person and strengthening social ties and ideas between people or groups [10]. Therefore, speaking is the main position in language activities because people talk more than they write in their daily lives.

As for the activities so that students can speak, especially in-class teaching by the teacher must be regular and not arbitrary or just from the road. Abdul 'Alim Ibrahim remembered the need to be considered by the teacher when teaching is that the teacher must be able to speak Arabic clearly, not hesitate when saying something and give a clear picture without mistakes and doubt that the students can follow what is said clearly and without defects. Then the teacher does not cut off the students' speech when speaking but waits when they finished reading and after that commented them. Besides, the teacher must use the question and answer pattern and the questions must be orderly, not carelessly asked students.

Other preparations for the teacher in teaching speaking skills are the teacher must prepare the material to be taught. Equip students with simple rules of information in speech such as expressions or idioms that are appropriate to express according to the conditions in which they are located. Doing questions and answers according to the material taught. And the teacher must be able to attract students to be invited to think what he is listening to until he can speak because it is the beginning he thinks then speaks [9]. And the last is the teacher can discuss with the students about the material being taught then assess the process during a teaching in the class. So the role of the teacher is very vital in the teaching process of speaking skills because it determines the success of students to spend courage in themselves so they can speak according to the material prepared by the teacher.

More than that, the teacher must know the level of teaching speaking skills so that the material will be given according to the portion and become a basic reference in writing and compiling teaching textbook material, this is because the background of children is different especially in senior high school. The levels are initial level, mid-level, and high level. At the initial level, it is still at the stage of repeating words or sentences whose process revolves around questions and answers between teacher and student. Furthermore, the mid-level increases from the initial level, which is to invite children to practice speaking directly by 
playing roles. Finally, the high level is where the students must have sufficient language and learning experience to speak, for example, discussion, storytelling, debate, description or speaking with a predetermined title [9]. In this way, the teaching material provided can have a real influence on the students because it fits the content and the portion is right.

However, it is not enough what has been described above to prove that students can speak according to their capacity, there is a need for instruments of training so that the teaching aims set at the beginning have not deviated. There are many forms of speaking skills teaching exercises as mentioned by Muhammad Ali al-Khuli. For example, the practice of answering written questions orally, repeating words or sentences, changing sentences, description of images, conversations, answering questions based on pictures, free expression, expressing time, etc. all of which are answered verbally [11]. But even so, the teacher can order students to answer in writing after they answered verbally. Thus, these forms of training help the teacher in the process of attracting students to express their abilities to speak and the teacher can measure the ability to the extent of the success achieved by each individual.

In addition to these forms, the criteria for the form of good practice are more binding on the stated goals of the material being taught. In summary, these criteria are validity, reliability, difference, representation, period, a form of instruction, assessment, and form of the question [11]. From these eight criteria, it can be ascertained the objectives and indicators by the teacher and students and they should understand the material so that they have learned well to improve their speaking skills.

Apart from above, other aspects that need to be considered in predicting the form of problems or difficulties from the side of students, teachers and the material in Arabic language teaching. This prediction helps to find out the location of the problems at the beginning and the mistakes that will be faced so that they do not occur continuously. First, from the student's side, that is the most basic is a shame because it is certain that this prevents students from speaking. Then they are still weak to think because of the limited wealth of language possessed and the language experience that both of this help very much in expression. Then the lack of motivation given through the family and fear of being wrong when speaking [4].

The next problem, from the teacher's side, is that the teacher has not been able to speak and use language clearly or fluently. Teachers pay less attention to the form of training given to students. The teacher's attention to the time to practice speaking is still lacking. The way to teach in the classroom is not following the students so the teacher is required to be more creative in teaching. And the most important thing is that the teacher motivates, in the beginning, to convince them to be confident when speaking. Then finally from the material side the selection of titles is not right for the development of students and less attention to the tendency of direction and difficulty of students, not identifying topics that will be taught accurately, not using or still not maximal in using visual aids such as images for stimulating students to talk, then speaking material is still considered a separate subject from other language skills and does not use appropriate evaluation forms.

\section{Communicative Aprroach}

In language learning, it is always associated with the terms approach, method, and technique. These three terms were born by Edward M. Anthony in his book Approach, Method, and Technique (1963). The approach is a set of assumptions related to the nature of language, learning, and teaching. The method is a comprehensive plan for presenting 
systematic language based on a particular approach. While the technique is special activities that are manifested in the class that are consistent with the method and in line with the approach [12]. From the above understanding, it can be seen that they are related to each other in language learning. Therefore, language instructors must understand these three things which are then able to implement them in language teaching.

Furthermore, from the three terms above the researchers focused on the communicative approach. According to Thu'aimah, the intention is contact between two people through various processes by involving thoughts and movements to convey thoughts, aims or expressions to each other [13]. This definition is the same as kalam as explained above. Even so, said by Muhammad Rusydi Khathir et al. not much different from the statement of Thu'aimah, only the difference between communication is carried out not only two people but can communicate in the social environment and be able to take extensive lessons and info from the communication that they do that [14].

More details said by Furqonul Aziez the communicative approach is learning that it focuses on approaches that not only teach mastery of foreign languages but also teach social skills, such as what to speak, how to speak, when to speak and where to speak to meet daily needs as greater purpose [15]. From the definitions before is in accordance which was said first by Ahmad Abduh 'Uud because humans learn a language to socialize in the community whose focus of teaching practice is to speak according to their life situation and he states that the communicative approach is the most important approach of other approaches in teaching any language [16]. From these definitions, it can be concluded that the communicative approach in teaching foreign languages that are being able to directly communicate with other people at certain levels of support or society, because this is the basic aim of learning any language.

Now in the communication process, there are components in the communicative approach. The first component is a message as the content or intention to be conveyed by the speaker in the form of good and proper language expression. The second is the sender, the source of the message and the first part of the communication process by influencing others in which the source of the message comes from one person but also a group. Then the third is the tools of carrying the source of this message can be directly through ordinary voice, or it can be recorded and broadcast. And the last is recipient, namely the place where the message was received from the sender, could be one person or group [13]. From these four components, it can be used as a basis in making teaching materials or materials according to their respective roles which are formed such as al-Muhadatsah or question and answer on certain topics.

In addition, to strengthen the material that will be designed in language teaching based on a communicative approach there are several characteristics that need to be considered according to Ahmad Fuad Effendy, as follows: 1) the purpose of teaching is to develop the competence of students to communicate with the target language such as real-life situations. 2) The basic concept is the meaningfulness of each form of language learned. 3) In the teaching-learning process, students act as active communicators while the teacher acts as a facilitator. 4) activities in the class are manifested tangibly and dominantly with activities, communicative, not drill manipulative and meaningless imitation. 5). The material presented is more emphasized on authentic materials, such as newspaper news, menus, forms and the like. 6) The use of mother tongue in class is not prohibited but minimized. 7) In a communicative approach, students' mistakes in speaking are tolerated to encourage the 
courage of students to communicate. 8) Evaluation is emphasized in the ability to use language in real life, not the mastery of language structure or grammar.

Then after knowing the characteristics to understand the role of the teacher, students, and the material itself. The teacher has an important role in language teaching in this approach, he must know the needs of students to be able to communicate in the destination language or second then analyze it following the communicative situation and then implement it in the form of practice in the classroom. While students are places where communication processes occur in the language teaching process of the material chosen by the teacher that has been prepared carefully and students must follow the conversation in the classroom directly with the practice. While the position of the material must be limited, such as not overestimating the vocabulary, but only as a complement to help understand dialogue in the communication process. Also, as said earlier the material must be authentic, practice alternately to speak so that courage increases or is not ashamed [17]. So in the textbook, the authors compose the contents and practices is always involve students to be able to speak and have good communication.

The next preparation step is how to apply the communicative approach to the syllabus. The syllabus itself is an outline of the teaching program which consists of four components such as aims, materials, methods, and evaluations. In connection with the communication approach Effendy said that the syllabus that corresponds to it is the semantic syllabus which is the main purpose of targeting language acquisition. Each of the units in the textbook illustrates certain contexts according to real life [18]. Through this syllabus, it helps anyone who composes teaching materials to stay focused on the main aim of growing students' speaking skills.

Therefore, the book that the authors compose to in the aspects of material selection based on a communicative approach as mentioned by Thu'aimah as follows: 1) That good material is material that changes student language competence to communicative competence with their different backgrounds. 2) Composing material must be based on an analysis of language needs according to students. 3) The material allows students to practice it and their practice can produce results according to the indicators set.

4) Material must provide a strong stimulus or motivation for students to learn languages by explaining the purpose of learning the material so that the child is motivated and the visualization of the book is interesting [13].

Another important point regarding the communicative approach is that this approach has advantages and disadvantages. This advantage is one of the reasons why the authors compile textbooks based on this approach that the interest of students motivated in learning and liked because they directly communicate with a foreign language or target. Students are fluent in communicating, in the sense of mastering at least public conversations that they are often involved in. Then the classroom atmosphere comes alive with communication activities between students with various interaction models so that it is not boring. As for the disadvantages, it requires teachers who master target language skills adequately, their reading and writing skills are slightly reduced, and direct jumps to communicative activities can make it difficult for students at the initial level.

\section{Conclusion}

From the explanation above, concluded that the Arabic language teaching needs to be 
continuously developed with various approaches, methods, and techniques to other than native speakers because their needs are different. In this case, researchers applied a communicative approach to senior high school students focusing on fostering their interest in learning Arabic by taking only one skill, namely speaking skills. This is because speaking skills are closely related to the communicative approach. $\mathrm{n}$ addition, in truth teaching, is not only about speaking skills that are emphasized but other skills remain only a little more. Its form is the material of textbooks that can be implemented directly to students. As one of its contents shows before this conclusion.

The researchers have chosen students of senior high school students as the object of research is an effort that needs and continues to be developed for the problems that occur in teaching Arabic at this level. Hopefully, this textbook can be a formula or alternative to teaching Arabic in senior high school despite the various problems that exist as mentioned above. And also after graduating from school at least they get more learning experience with Arabic and are even motivated to learn and practice more intensively.

Below is one example of a textbook contents unit that the authors have composed it. 


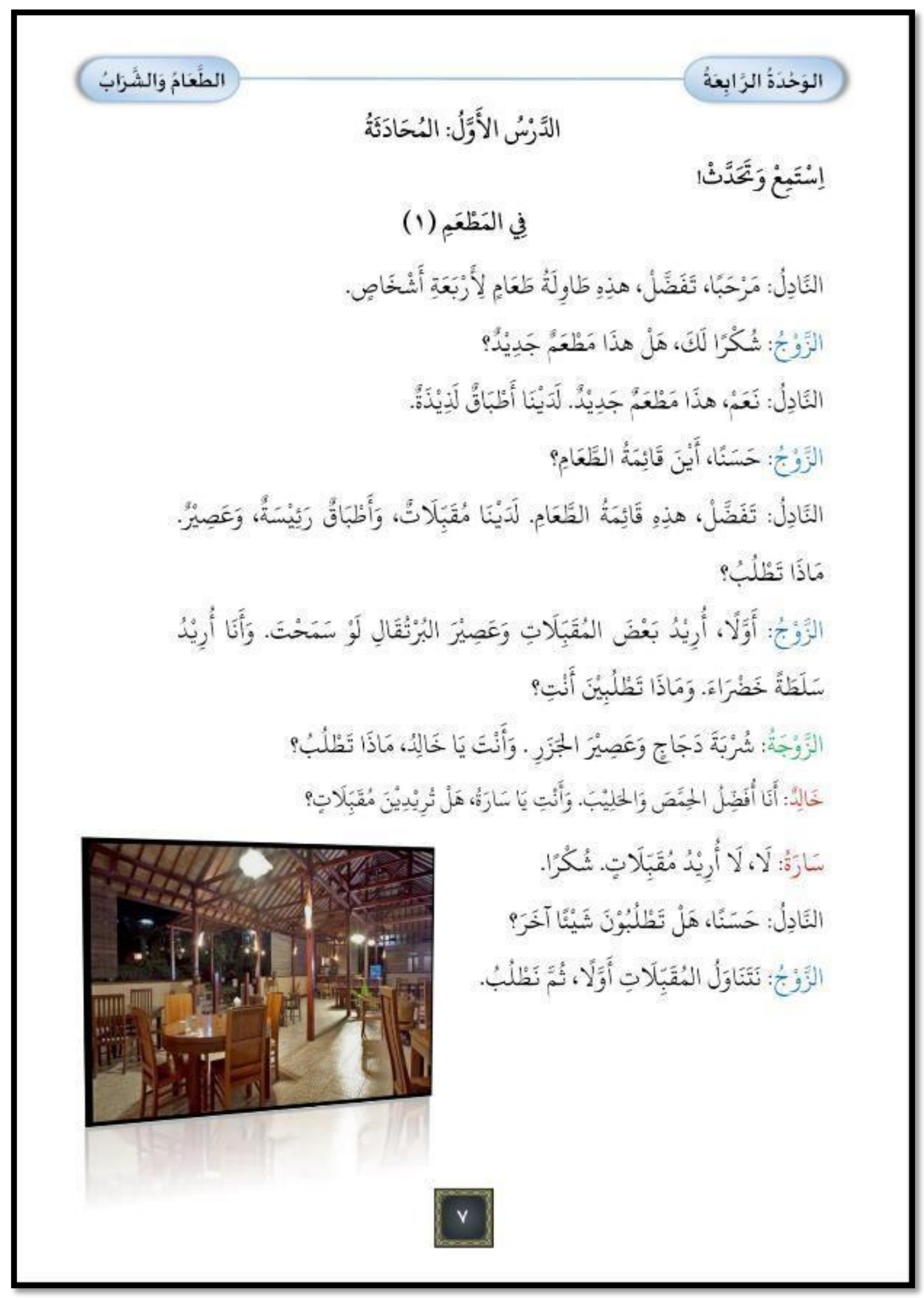




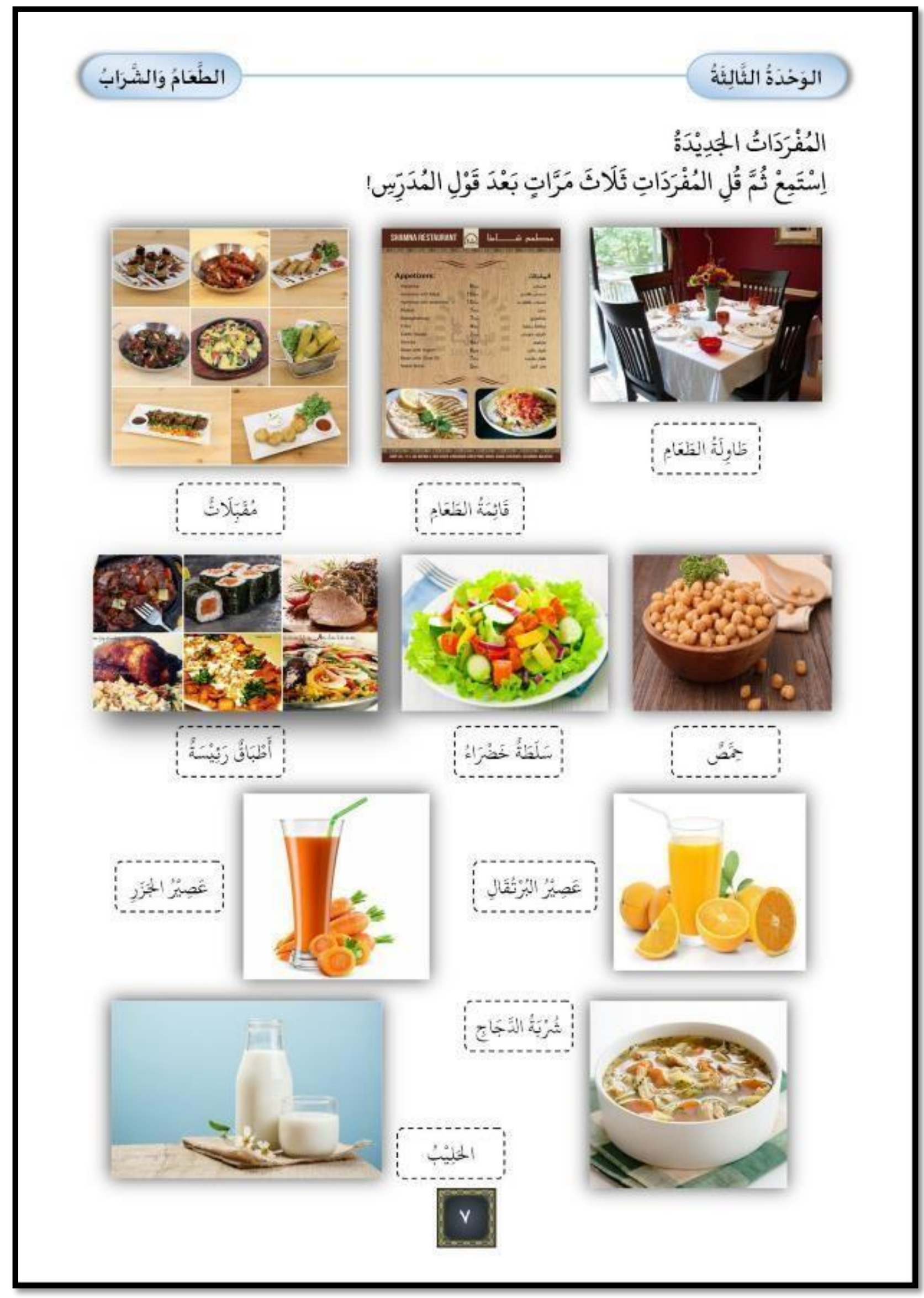




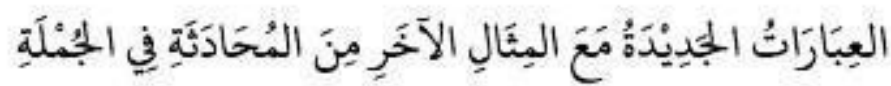

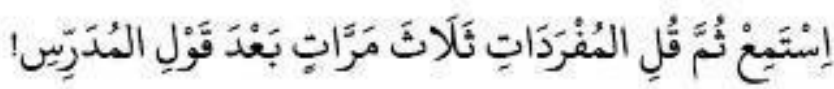

\begin{tabular}{|c|c|}
\hline & مَرْحَبَّا \\
\hline 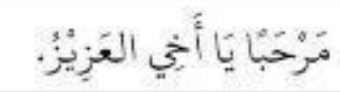 & 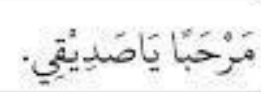 \\
\hline
\end{tabular}

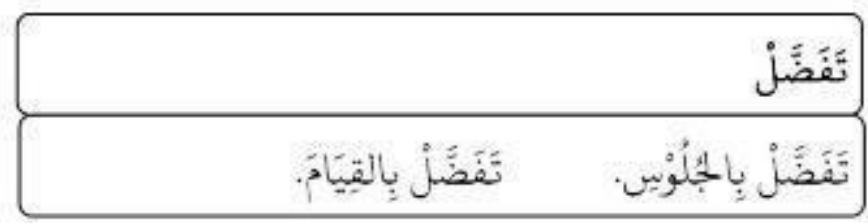

شُكْرَالَكَّ

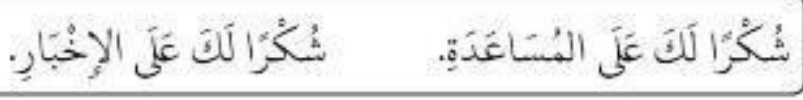
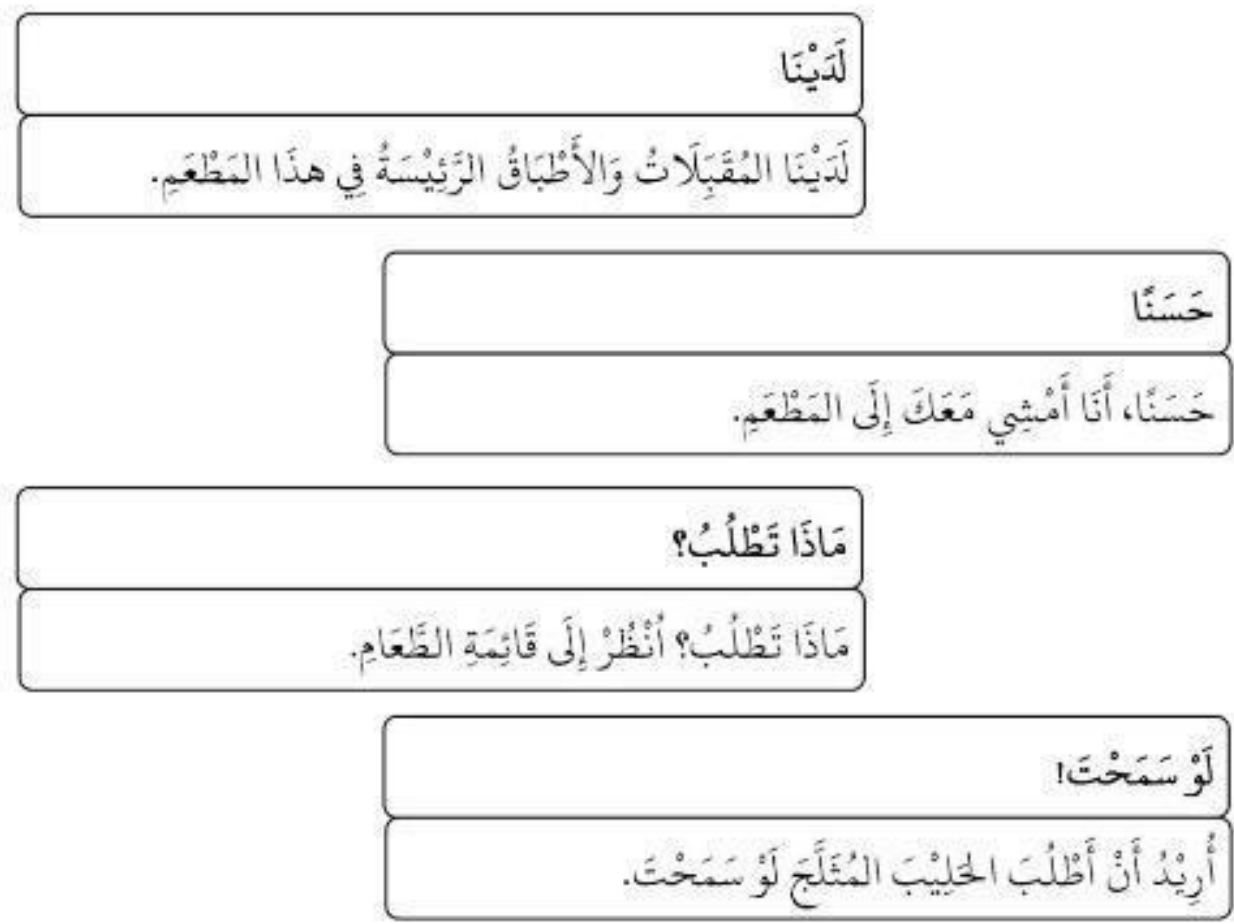


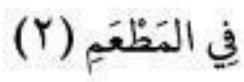

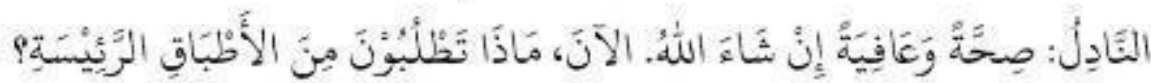

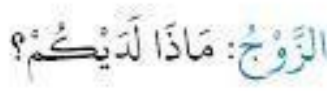

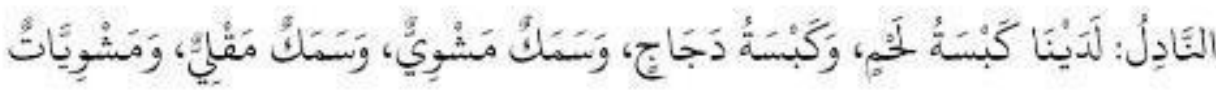

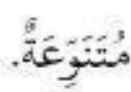

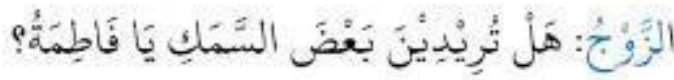

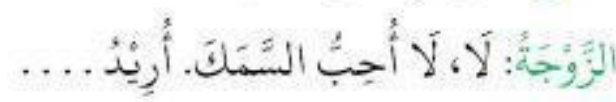

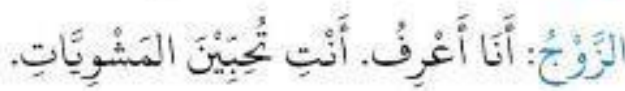

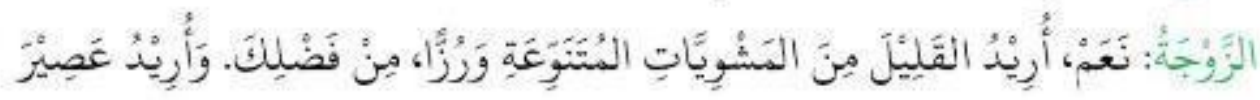

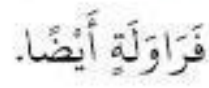

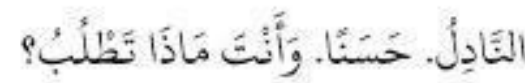

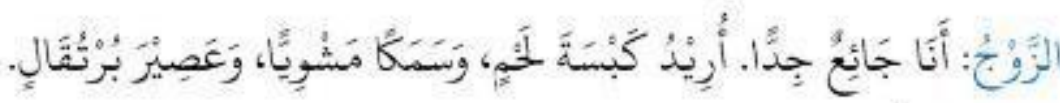

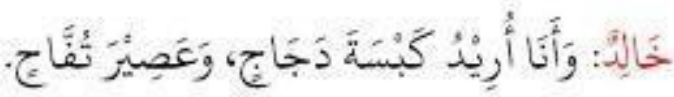

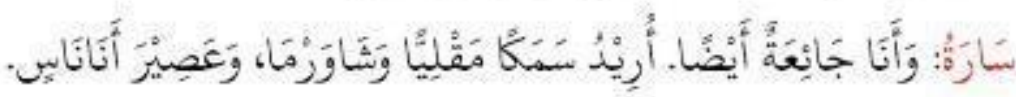

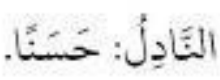

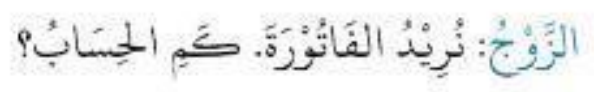

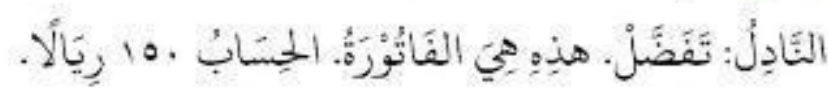




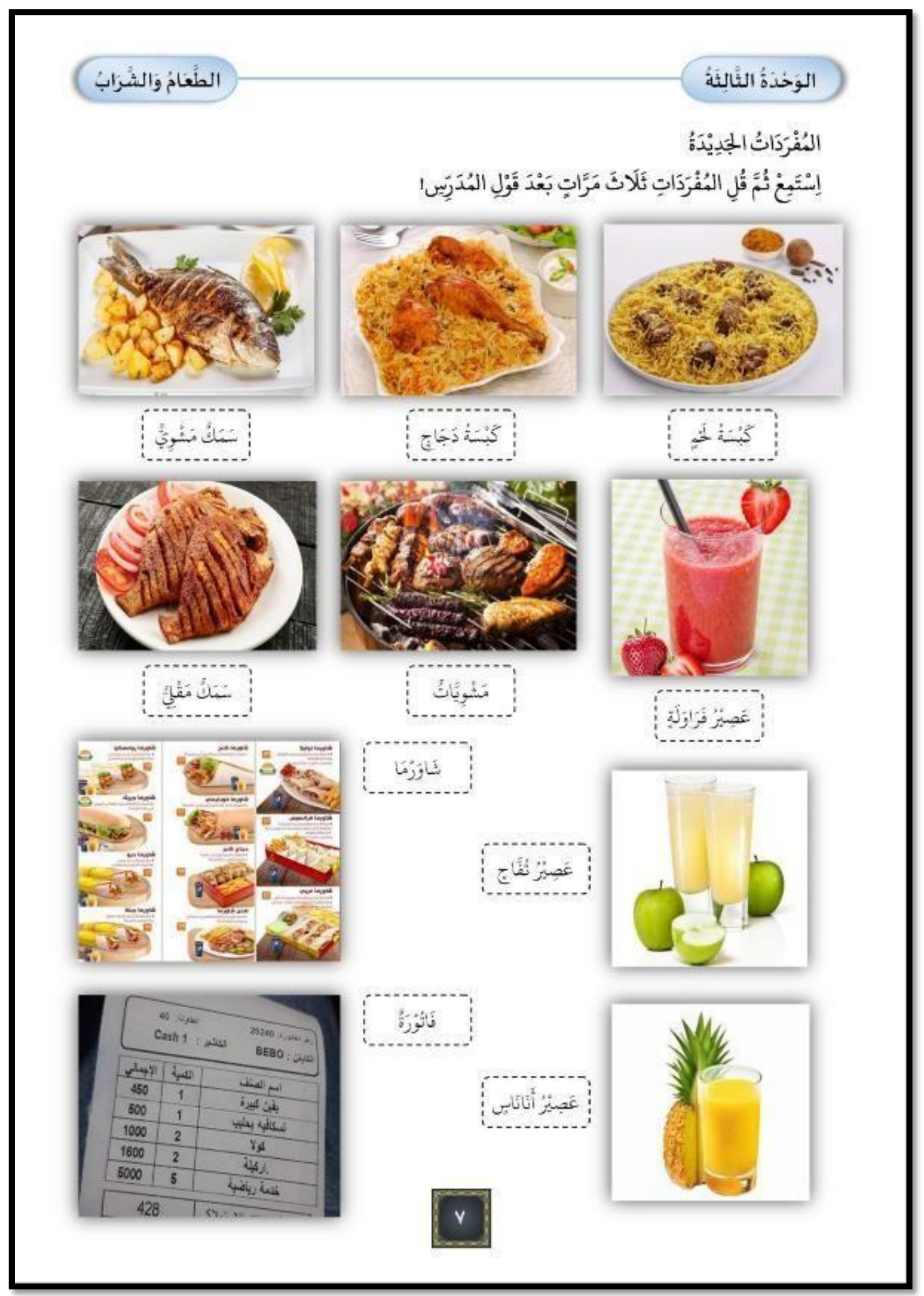




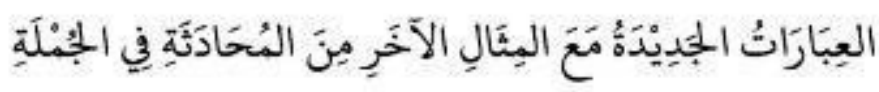

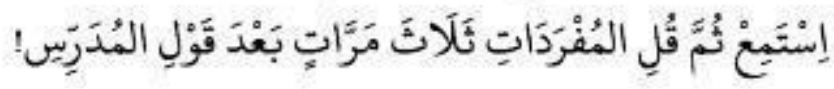

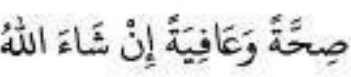

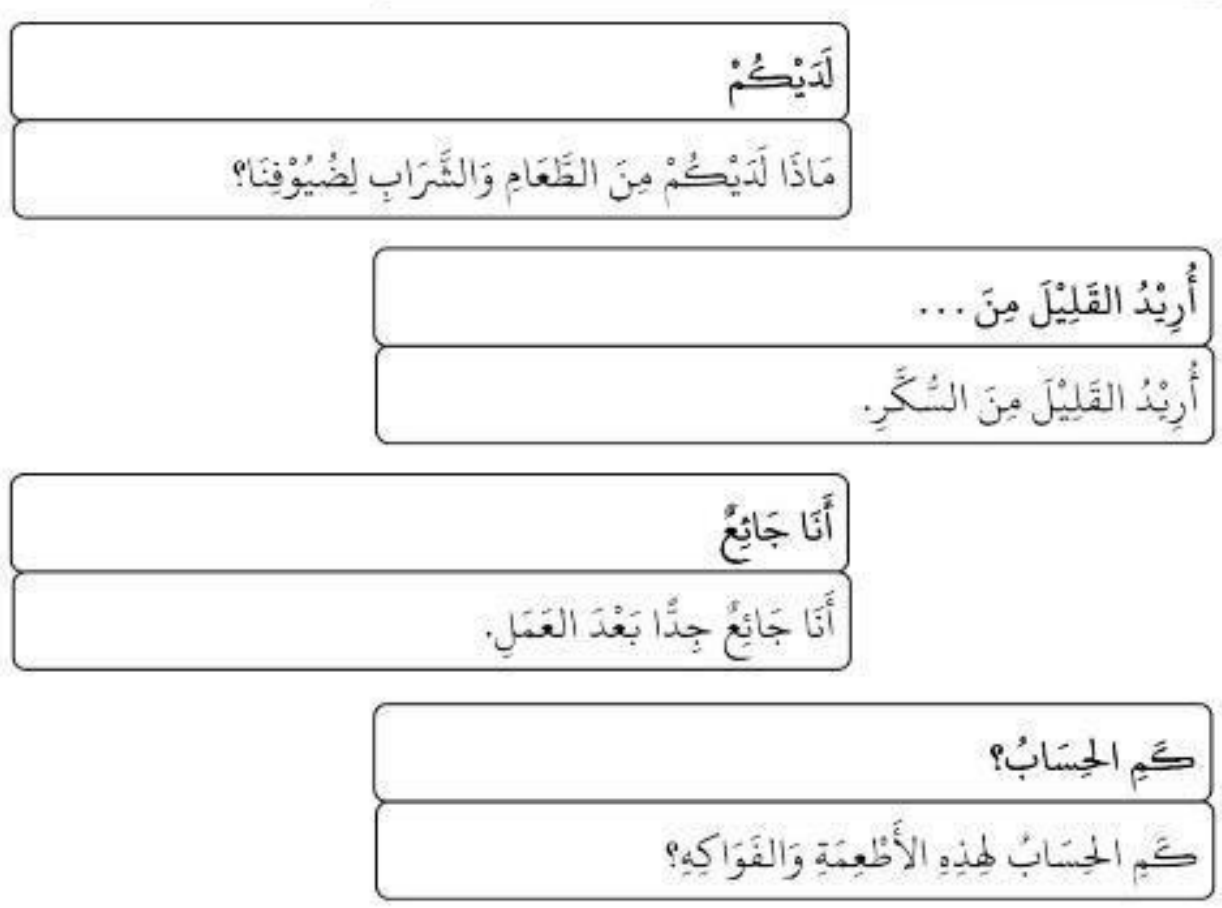




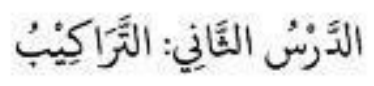

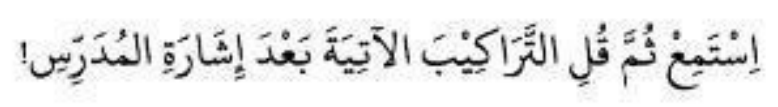

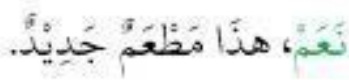

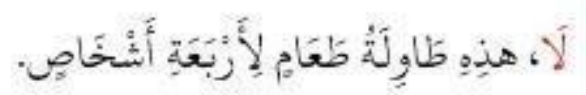

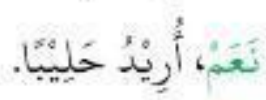

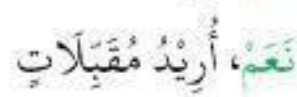

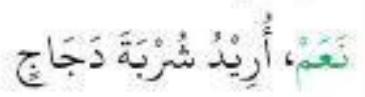

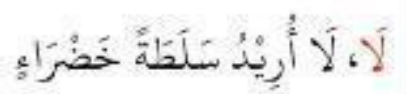

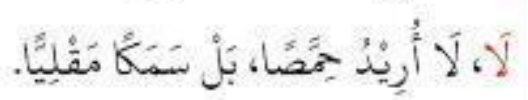

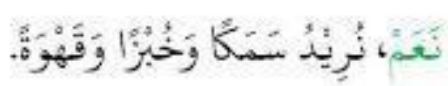

لأَاُشُكَرَا.

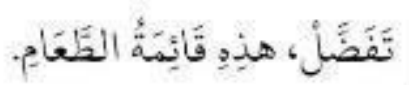

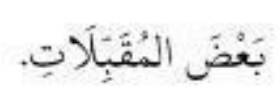

مِنْ فَضْلِكَ

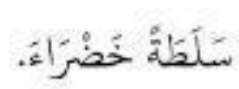

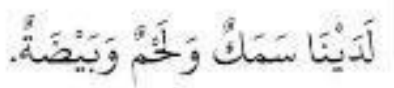

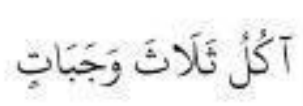

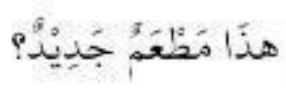

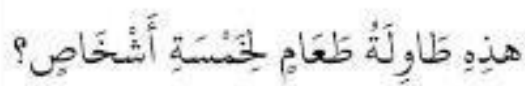

حَليْيَّنَ.

تُرِيْدُ

مُقَبَّلَاتِ

شَرْبَة دَجَاهِهْ

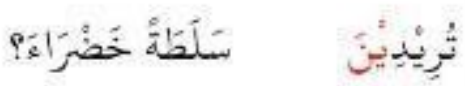

?

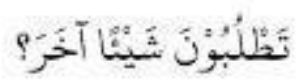

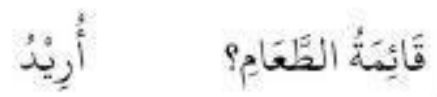

أُرِيندُ

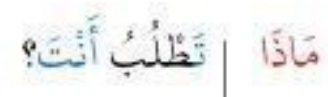

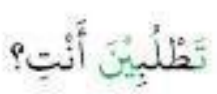

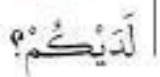

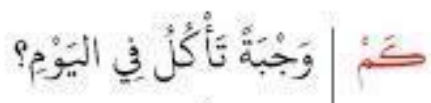

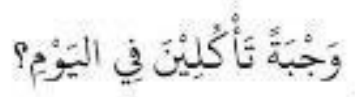




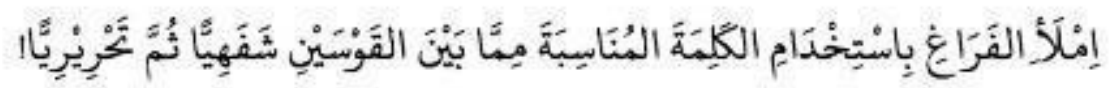

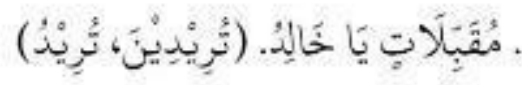
is.

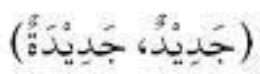

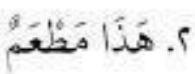

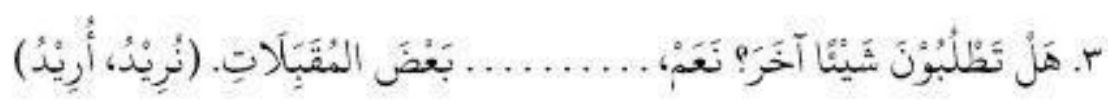

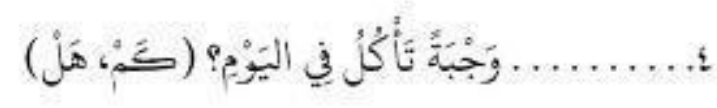

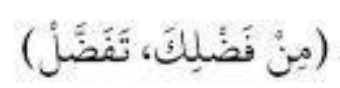

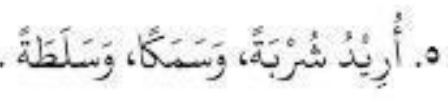

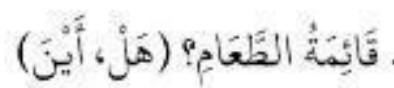

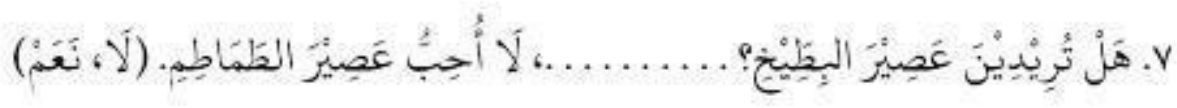

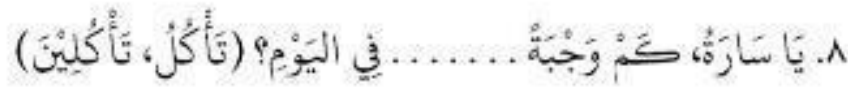




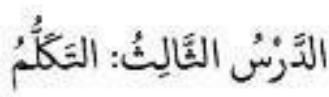

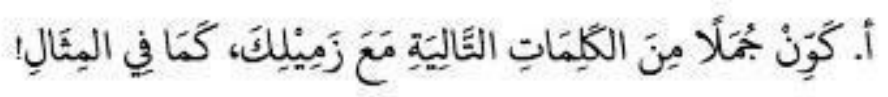

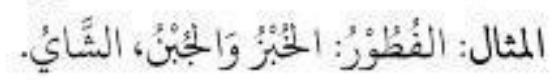

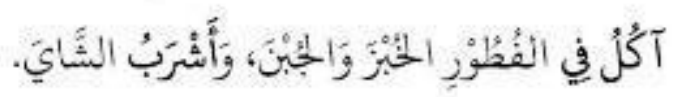

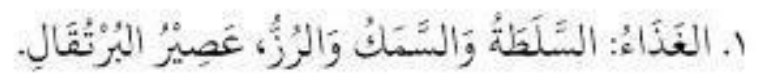

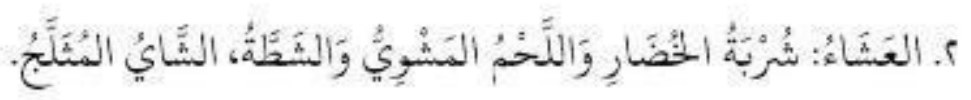

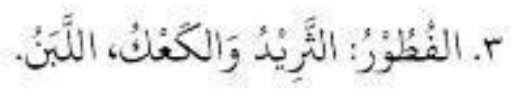

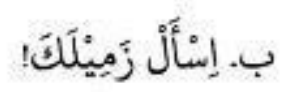

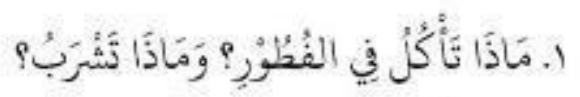

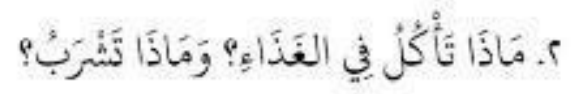

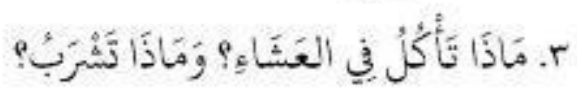

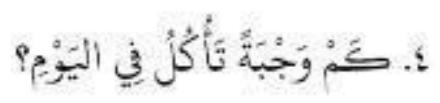

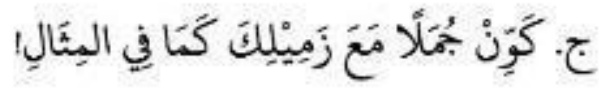

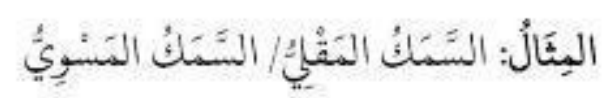

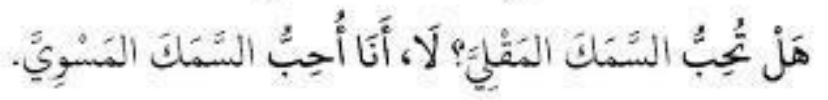

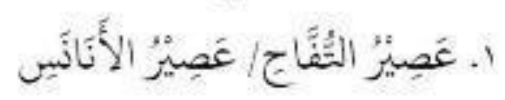

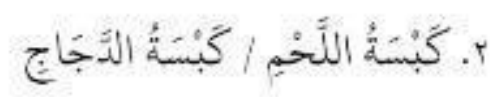

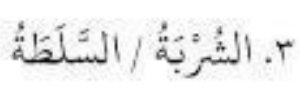

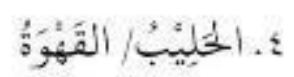




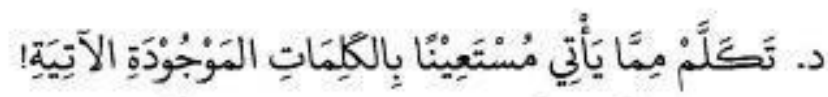

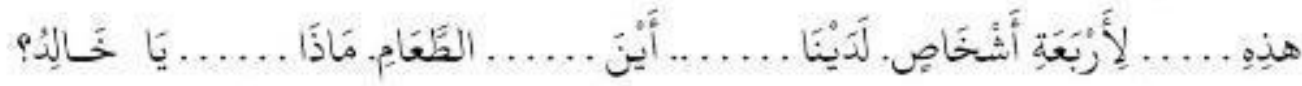

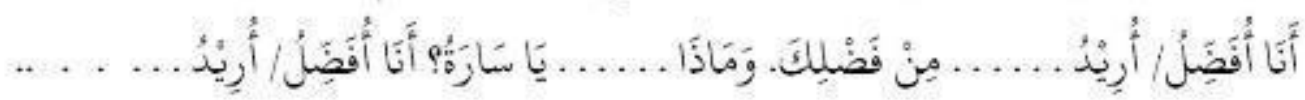

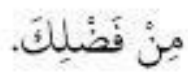




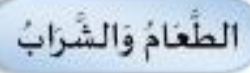

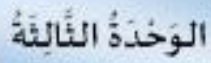

$$
\text { الدَرَُّ الرَّابِع: القِرَرَاءةُ }
$$

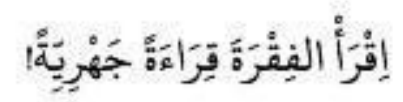

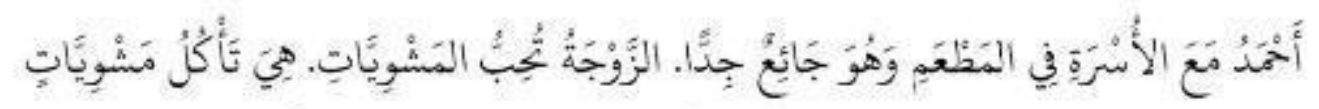

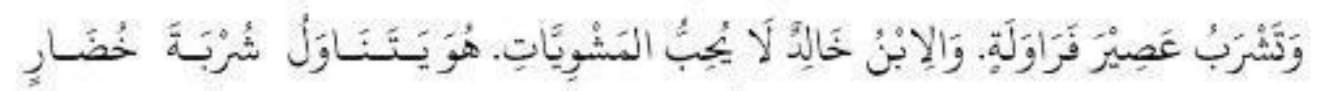

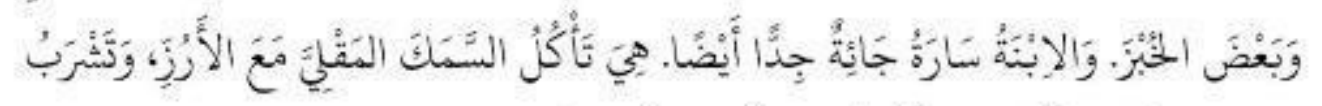

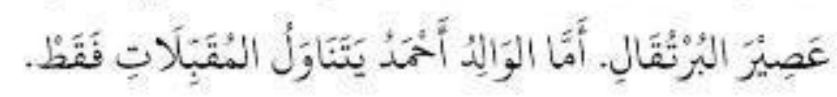

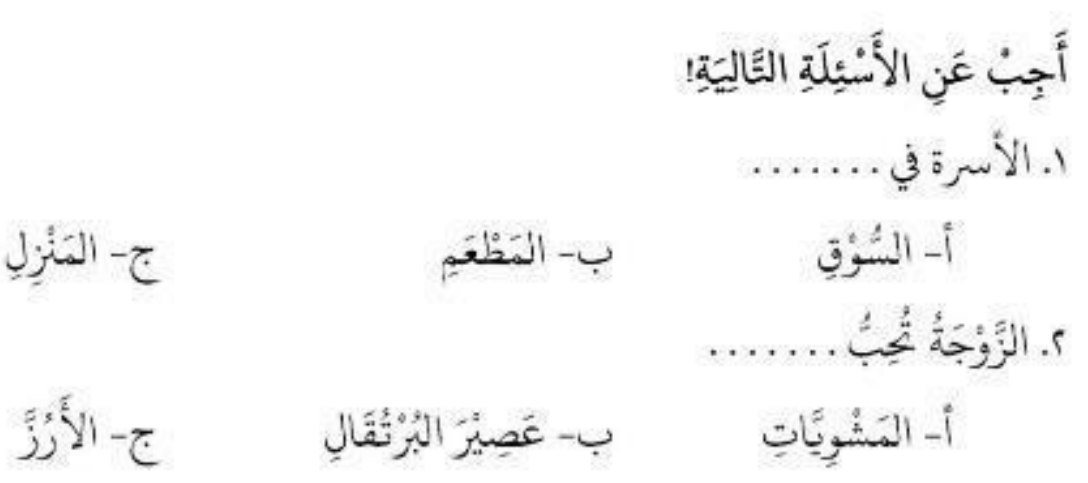

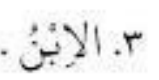

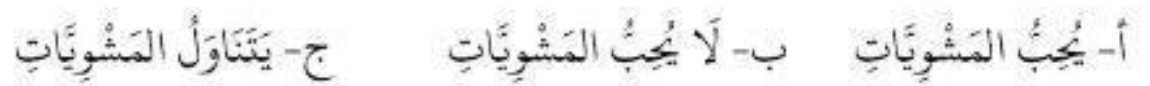

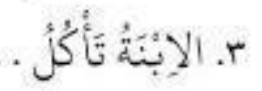

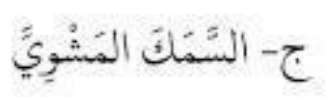

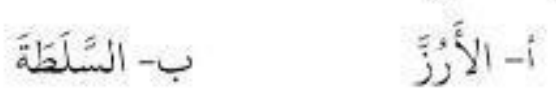

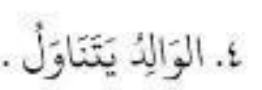

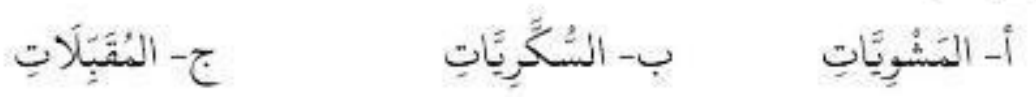




\section{References}

[1] Majmu'atu al-Bahisin, al-Lughah al- 'Arabiyah fi Indonesia. Riyadh: Dar Wujuh Li an-Nasyr wa at-Tauzi', 2015.

[2] A. A. Madkur, Tadris Funun al-Lughah al-'Arabiyah. al-Qahirah: Dar al-Fikr alAraby, 2006.

[3] N. Hizbullah and Z. Mardiah, "Masalah Pengajaran Bahasa Arab di Madrasah Aliyah di Jakarta,"

Al Azhar Indoenesia Seri Hum., vol. 2, no. 3, March, 2014.

[4] K. M. M. 'Irfan, Ahdats al-Ittijahat fi Ta'lim wa Ta'allum al-Lughah al'Arabiyah. Riyadh: Dar an-Nasyr ad-Duwali, 2008.

[5] Hudson, 'Ilmu al-Lughah al-Ijtima'i. Mesir: 'Alim al-Kutub, 2002.

[6] N. Al-Khuri, al-I'lam al- 'Araby wa Inhiyari as-Sulthat al-Lughawiyah. al-Mamlakah al-'Arabiyah as-Su'udiyah: 'Imadatu asy-Syuunu al-Maktabat, 1988.

[7] M. S. F. al-H. wa Ashabuhu, al-Istiratijiyat wa Maharah al-Ittisal at-Tarbawy. Jordan: Dar shafa li an-Nasyr wa at-Thiba'ah, 2011.

[8] M. S. abdu Al-Bari, Maharah at- Tahaddust al-'Amaliya wa al-Adaa. Amman: Dar al-Masirah, 2011.

[9] R. A. Thu'aimah, Ta'lim al- 'Arabiyah Lighairi an-Nathiqina Biha: Manahijuhu wa Asalibihi. Mansyurat al-Munazhamah al-Islamiyyah li at-Tarbiyah wa al'Ulum wa ats-Tsaqafah, 1989.

[10] A. I. Shuman, Dirasat fi Tanmiyati Maharah at-Tahaddust wa al-Kitabah li Thalabati al- Marhalah al-Asasiyah. al-Mamlakah al-Urduniyah alHasyimiyah: Dar Jalis az-Zaman, 2010.

[11] M. A. Al-Khuli, al-Ikhtibarat al-Lughawiyah. Urdun: Dar al-Falah, 2000.

[12] D. Andri Wicaksono, Ahmad Subhan Roza, Teori Pembelajaran Bahasa: Suatu Catatan Singkat. Yogyakarta: Garudhawaca, 2016.

[13] R. A. Thu'aimah, al-Maharah al-Lughawiyah Mustawayatuha, Tadrisuha, Su'ubatuha. al-Qahirah: Dar al-Fikr al-'Araby, 2004.

[14] M. R. T. Dkk., Thuruq at-Tadris al-Lughah al-'Arabiyah wa at-Tarbiyah adDiniyah fi Dhoui al-Ittijahat at-Tarbiyah al-Haditsah. al-Qahirah: Muthabi’ Sajal al-'Arab, 1989.

[15] F. Aziez, Pengajaran Bahasa Komunikatif: Teori dan Praktik. Yogyakarta: Pustaka Pelajar bekerja sama dengan UM Purwokerto Press, 2015.

[16] A. A. 'Uud, Madakhil Ta'lim al-Lughah al-'Arabiyah Dirasah Naqdiyah Mashiyah. al-Mamlakah al-'Arabiyah as- Su'udiyah Wizarah at-Ta'lim al-'Ali: Jami'ah Ummu al-Qurra, 2000.

[17] A. A. I. Al-'Ashili, Tharaiq Tadris al-Lughah li an-Nathiqina bi lhughatin Ukhra. Jami'ah al- Imam Muhammad bin Su'ud al-Islamiyyah, 2002.

[18] A. F. Effendy, Metodologi Pengajaran Bahasa Arab, Cetakan 7. Malang: Misykat, 2017. 